\title{
Bilateral endogenous fungal endophthalmitis secondary obstructive pyelonephritis
}

\author{
Endoftalmite fúngica endógena bilateral \\ secundária a pielonefrite obstrutiva
}

Italo Antunes França Barbosa ${ }^{1}$, Ana Cláudia Viana Wanzeler ${ }^{1}$, Higor Alexandre Pavoni Gomes ${ }^{1}$, Kellen Cristiane do Vale Lúcio ${ }^{1}$, Eliane Chaves Jorge', Silvana Artioli Schellini ${ }^{1}$

\begin{abstract}
The authors report a case of bilateral endogenous fungal endophthalmitis occurred after decompression nephrostomy due to secondary obstructive pyelonephritis the treated nephrolithiasis initially with intravitreal voriconazole $(100 \mathrm{mg} / 0.1 \mathrm{ml})$ but evolved without therapeutic response requiring the posterior vitrectomy (23G).

Keywords: Pyelonephritis/complications; Endophthalmitis/etiology; Endophthalmitis/drug therapy; Fungal eye infections; Voriconazole/therapeutic use; Vitrectomy; Case reports
\end{abstract}

\section{Resumo}

Os autores relatam um caso de endoftalmite fúngica endógena bilateral ocorrida após nefrostomia descompressiva decorrente de pielonefrite obstrutiva secundária a nefrolitíase tratada, inicialmente, com injeção intravítrea de voriconazol (100 ìg/0.1 ml) porém evoluiu sem resposta terapêutica sendo necessária a vitrectomia posterior $(23 \mathrm{G})$.

Descritores: Pielonefrite/complicações; Endoftalmite/etiologia; Endoftalmite/quimioterapia; Infecções oculares fúngicas; Voriconazol/uso terapêutico; Vitrectomia; Relatos de casos

'Department of Ophthalmology, Faculdade de Medicina de Botucatu, Universidade Estadual Paulista "Júlio de Mesquita Filho"-Botucatu, SP, Brazil. Study carried out at Faculdade de Medicina de Botucatu, Universidade Estadual Paulista "Júlio de Mesquita Filho" - Botucatu, SP, Brazil. The authors declare no conflicts of interests.

Received for publication 16/02/2016 - Accepted for publication 04/03/2016 


\section{INTRODUCTION}

$\mathbf{F}$ ungi are the most common agents in endogenous endophthalmitis, represented in most cases by Candid $a^{(1)}$. In the last decades, the increase in incidence has been influenced by several factors, such as the diffusion of antibiotic therapy, intravenous catheterization, the use of prolonged parenteral nutrition, immunosuppression caused by systemic disease or induced immunosuppressive therapy, the use of illicit drugs and prematurity at birth ${ }^{(2)}$.

Currently, amphotericin B is used as first-line treatment in fungal endophthalmitis, despite its local and systemic toxicity. The emergence of azole antifungals that have lower rates of side effects and the possibility of oral administration has been presented as an alternative to amphotericin $\mathrm{B}^{\left({ }^{(3)} \text {. Voriconazole is }\right.}$ a second generation triazole agent active against all Candida species, including resistant strains. Some cases have been described regarding the therapeutic success of voriconazole in patients with fungal endophthalmitis ${ }^{(4)}$.

The present report aims to show a case of bilateral endogenous fungal endophthalmitis which occurred after decompressive nephrostomy due to obstructive pyelonephritis secondary to nephrolithiasis, treated with posterior vitrectomy and intravitreal injection of voriconazole.

\section{CAse Report}

White female patient, 59 years old, from Brotas, São Paulo, attended at the ophthalmology department at Faculdade de Medicina de Botucatu - São Paulo, with a complaint of progressive low visual acuity in the right eye (RE) for 60 days, a little pain, photophobia and hyperemia, followed by the left eye (LE) 20 days afterwards. One month before the onset of the ocular condition the patient had obstructive pyelonephritis with right-sided pyonephrosis secondary to nephrolithiasis and treated with decompressive nephrostomy and antibiotic therapy. Due to her severe general condition, she was admitted to the intensive care unit for three days with a central venous catheter. Hemoculture was positive for Candida albicans, having started treatment first with intravenous Fluconazol and later orally. The following comorbidities were shown: systemic arterial hypertension, cholecystectomy, three previous nephrostomies, atrioseptoplasty with bovine pericardial flap 25 years before; she denied diabetes mellitus, smoking and alcoholism. She was in use of Dexamethasone $0.1 \%$, Atropine and Fluconazol 150mg 2 tablets every 12hours for 6 days. The ophthalmologic examination showed visual acuity (VA) without correction in finger counting at 1 meter in the RE and in finger counting at 2 meters in the LE, conjunctival hyperemia 2/4+, ciliary injection, cornea with diffuse fine ceramic precipitates, anterior chamber reaction 4+ and bilateral flare 3+, hypopyon with level $<1 \mathrm{~mm}$ in the right eye, drug mydriasis in both eyes, opalescent crystalline. Fundoscopy showed intense vitreitis (3+), $\mathrm{RE}$ retina with whitish cotton ball-like lesions temporarily to the macula and in the LE adjacent to the macular region and optic disc (Figure 1). The patient was hospitalized and the medications were replaced by Prednisolone 1\% every 2 hours, Tropicamide everu 8 hours, and Fluconazole 400mg every 12 hours EV. A vitreous puncture was carried out associated to intravitreal injection of Voriconazole, first in the LE, as described. patient in supine position, antisepsis and placement of sterile fields, blepharostat, instillation of eyedrops Proximetacaine (Anestalcon, Alcon, Brazil) and Iodopovidone $5 \%$, puncture of $0.2 \mathrm{ml}$ of vitreous with needle of $27 \mathrm{G}$ at $4 \mathrm{~mm}$ of the limb in the superior temporal region, and injection of $100 \mathrm{ig} / 0.1 \mathrm{ml}$ of Voriconazole. As there was no improvement in the ophthalmologic condition, five days after the injection a posterior vitrectomy was performed via pars plana $(23 \mathrm{G})$ using balanced saline solution as a vitreous substitute, without reapplication of voriconazole intraoperatively. The clinical improvement of the patient was waited, and after 1 month the same procedures were performed in the RE. All blood cultures and vitreous cultures collected at the time of the interventions - intravitreal injection and vitrectomy - were negative even 2 weeks after collection. It evolved with dense posterior subcapsular cataract and bilateral macular epiretinal membrane. Phacoemulsification was held with intraocular lens implant inside the capsular sac (LIO +21.50, SRKT formula, axial length
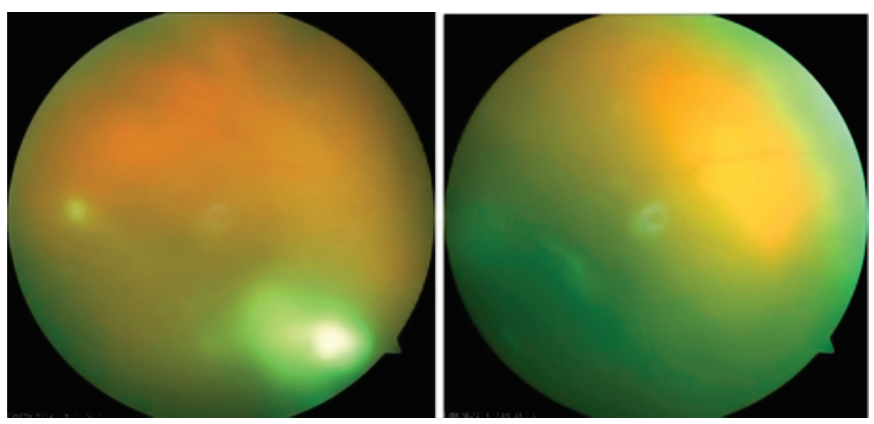

Figure 1: Bilateral intense vitreitis. Right eye with whitish cotton ball type lesions temporarily the macula and in the left eye adjacent to the macular region and optic disc.
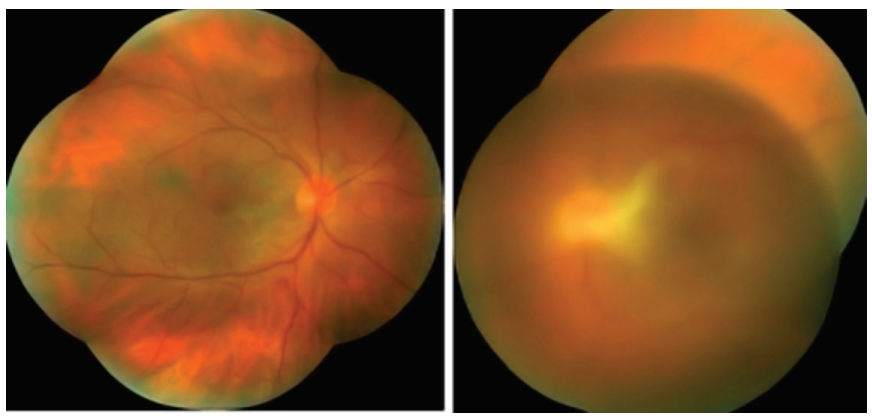

Figure 2: Post-operative posterior vitrectomy via pars plana RE.
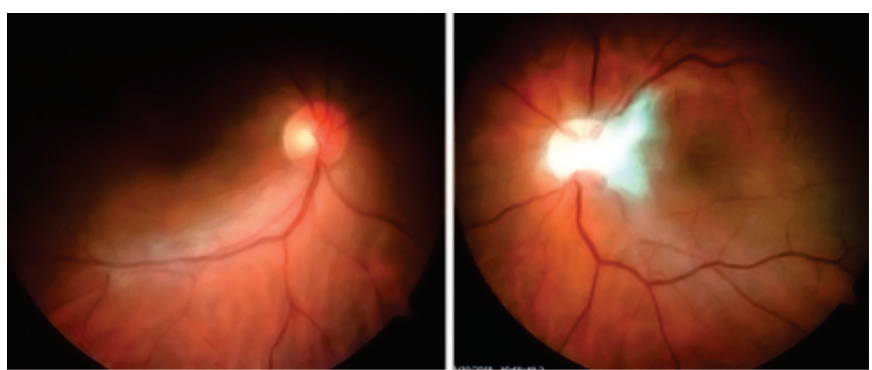

Figure 3: Post-operative posterior vitrectomy via bilateral pars plana and presence of fibrotic scar membrane on the LE optic disc. 
22.37mm, K45.00@ 180x47.25@ 90,AR40 and Sensar Abbott, 3 parts) was performed in the LE, and later a surgery was made combined with phacoemulsification associated to posterior vitrectomy $(23 \mathrm{G})$ and peelingof the macular membrane in the $\mathrm{RE}$ using triamcinolone and bright blue (Figures 2 and 3). Procedures performed without intercurrences. Currently, it presents corrected VA of 0.2/0.1, despite the macular membrane in the LE.

\section{Discussion}

The authors report a case of bilateral endogenous fungal endophthalmitis following nephrolithiasis complicated by obstructive pyelonephritis in an adult female patient who had some risk factors for fungal infection known as: recent hospitalization, central venous access, and severe upper urinary tract infection ${ }^{(2)}$.

Fungal endophthalmitis is usually an indolent bilateral infection in $1 / 4$ of cases, and the most common symptoms are visual blur and photophobia. The characteristic ophthalmological sign is the presence of a white, elevated and poorly delimited lesion involving the choroid and retina, located in the posterior pole, which may be single or multiple ${ }^{(5)}$, as presented by the patient in this case.

The presumptive diagnosis was established from the ocular clinical condition and blood culture positivity for Candida albicans, performed in another service, since all blood cultures and vitreous humor cultures performed during hospitalization were negative, most likely because the patient had previous been treated for systemic antifungal therapy with Fluconazole. In a series of cases of fungal endophthalmitis, the vitreous samples collected by vitrectomy produced positive results in $92 \%$ of eyes when this method was used as initial treatment ${ }^{(6)}$. On the other hand, it has been demonstrated that in cases of endophthalmitis after cataract surgery, only in $24 \%$ of the vitreous samples the pathogenic agent was identified by culture exam, against $92 \%$ when compared to the polymerase chain reaction (PCR) ${ }^{(7)}$. Although this last exam offers superior results in the detection of pathogens, especially in cases of low pathogen counts, its use is not routine due to the high cost, and there was no access to this technology for the patient described here.

The presence of juxtapositional lesions implies a worse final visual prognosis, and is an indication for intravitreal injection or vitrectomy. Voriconazole shows $96 \%$ bioavailability after oral administration, and reaches a therapeutic level in the vitreous and aqueous in non-inflamed human eyes ${ }^{(8)}$. The intravitreal concentration of voriconazole in rabbits exhibited exponential decay time with a half-life of 2.5 hours, reaching undetectable levels after 8 hours ${ }^{(9)}$. Despite the reports of therapeutic success with oral ${ }^{(10)}$ or intravitreal ${ }^{(9)}$ voriconazole use, in the case described there was no improvement in the condition after the injection with voriconazole, which may be justified by the fact that a single injection was made, and not the daily doses until the lesion remission, as recommended ${ }^{(11)}$, with surgical treatment with posterior vitrectomy via pars plana being the option. It was also taken into account for the indication of the surgical procedure the fact of the bilateral visual impairment, which could assure a fast improvement of the VA with the surgery and, consequently, a better quality of life for the patient, besides her good general condition to undergo general anesthesia.
Postoperative follow-up is necessary due to the high risk of retinal detachment after posterior vitrectomy ${ }^{(6)}$ and formation of epiretinal membranes (ERM), a frequent complication of uveitis with significant impairment of visual function ${ }^{(12)}$. The prevention of the formation is based on the aggressive control of the inflammation; when present, surgical treatment with posterior vitrectomy and peeling of the ERM improves or stabilizes the VA when macular traction is proven. In the absence of traction, the results are variable and unpredictable ${ }^{(13)}$. A $1 \mathrm{t} \mathrm{h} \mathrm{o} \mathrm{u} \mathrm{g} \mathrm{h}$ endogenous fungal endophthalmitis is considered a serious ocular condition associated to poor visual results ${ }^{(14)}$, the final VA of this patient can be considered satisfactory, which excites us to indicate this procedure. One must also pay attention to the high degree of mortality that accompanies this, since we are dealing with critical patients.

\section{RefERenCES}

1. Clinch TE, Duker JS, Eagle RC Jr, Calhoun JH, Augsburger JJ, Fischer DH. Infantile endogenous Candida endophthalmitis presenting as cataract. Surv Ophthalmol. 1989;34(2):107-12.

2. Dotto PF et al. Uso do fluconazol endovenoso no tratamento da endoftalmite fúngica endógena: relato de caso. Arq Bras Oftalmol. 2005;68(4):543-6.

3. Müller GG, Kara-José N, Castro RS. Antifúngicos em Infecções oculares: Drogas e vias de Administração. Rev Bras Oftalmol. 2013;72(2):132-41.

4. Riddell IV J, Comer GM, Kauffman CA. Reviews of anti-infective agents - treatment of endogenous fungal endophthalmitis: focus on new antifungal agents. Clin Infect Dis. 2011; 52(1):648-53.

5. Palmer EA. Endogenous Candida endophthalmitis in infants. Am J Ophthalmol. 1980; 89(3):388-95.

6. Lingappan A, Wykoff CC, Albini TA, Miller D, Pathengay A, Davis JL, Flynn HW Jr. Endogenous Fungal Endophthalmitis: Causative organisms, management strategies, and visual acuity outcomes. Am J Ophthalmol. 2012;153(1):162-6.

7. Lohmann CP, Linde HJ, Reischl U. Improved detection of microorganisms by polymerase chain reaction in delayed endophthalmitis after cataract surgery. Ophthalmology. 2000;107(6):1047-52.

8. Hariprasad SM, Mieler WF, Holz ER, Gao H, Kim JE, Chi J, et al. Determination of vitreous, aqueous, and plasma concentration of orally administered voriconazole in humans. Arch Ophthalmol. 2004 122(1):42-7.

9. Shen YC, Wang MY, Wang CY, Tsai TC, Tsai HY, Lee YF, Wei LC. Clearance of intravitreal voriconazole. Invest Ophthalmol Vis Sci. 2007;48(5):2238-41.

10. Raju Biju, Daniel Sushil, and Nainan K Georgy. Successful management of presumed Candida endogenous endophthalmitis with oral voriconazole Indian J Ophthalmol. 2009 57(4):306-8.

11. Mithal K, Pathengay A, Bawdekar A, Jindal A, Vira D, Relhan N, Choudhury H, et al. Filamentous fungal endophthalmitis:results of combination therapy with intravitreal amphotericin B and voriconazole. Clin Ophthalmol. 2015;9:649-55.

12. Nicholson BP, Zhou M, Rostamizadeh M, Mehta P, Agrón E, Wong W, at al. Epidemiology of epiretinal membrane in a large cohort of patients with uveitis. Ophthalmology. 2014;121(12):2393-8. 
13. Tanawade RG, Tsierkezou L, Bindra MS, Patton NA, Jones NP. Visual outcomes of pars plana vitrectomy with epiretinal membrane peel in patients with uveitis. Retina. 2015;35(4):736-41.

14. Schiedler V, Scott IU, Flynn HW, Jr, Davis JL, Benz MS, et al. Culture-proven endogenous endophthalmitis: clinical features and visual acuity outcomes. Am J Ophthalmol. 2004; 137(4):725-31.

\section{Corresponding author:}

Italo Antunes França Barbosa

Rua Hermantino Coelho, 691; Apto 72, Torre 2- Mansões Santo Antônio, Campinas/SP

ZIP Code 13087-500

E-mail: italo_antunes88@yahoo.com.br 